\title{
Kesuksesan Belajar-Mengajar dan Mengabdi di Perguruan Tinggi (Universitas Kristen Indonesia Maluku - UKIM)
}

\author{
Claartje Pattinama \\ Dosen Pastoral dan Psikologi pada Fakultas Teologi UKIM \\ e-mail: claartjepattinama33@gmail.com
}

\section{Pengantar}

Membahas kesuksesan belajar-mengajar di Perguruan Tinggi, khususnya di Universitas Kristen Indonesia Maluku, paling tidak ada empat (4) faktor yang dapat dikatakan sangat menentukan kesuksesan tersebut antara lain: komitmen, motivasi, dukungan sosial dan selfefficacy. Keempat faktor ini saling berkaitan dan saling mempengaruhi dalam menentukan kesuksesan seseorang, termasuk kesuksesan semua elemen perguruan tinggi (mahasiswa, dosen, dan karyawan).

\section{Komitmen}

Klinger (Frank, 2001) mengemukakan bahwa konsep komitmen digunakan pada beberapa hal, dan telah digunakan pada beberapa keadaan. Menurut Klinger dalam Frank menjelaskan bahwa komitmen ada hubungannya dengan motivasi, komitmen menunjuk pada beberapa aspek dari kebulatan tekad atau ketetapan hati seseorang untuk mengejar cita-citanya. Selanjutnya dijelaskan bahwa kata komitmen, menunjuk pada apapun yang membuat seseorang melanjutkan atau meneruskan tindakannya karena adanya pengaruh positif, atau sebaliknya melepaskan atau meninggalkannya jika mengalami kesulitan. Dengan demikian dapat dikatakan bahwa komitmen mencakup makna atau pengertian yang berbeda-beda.

Brickman (1987) mendefinisikan komitmen sebagai ketekunan dalam mengerjakan atau menjalani suatu aktifitas yang penting dan bermakna, meskipun ada tantangan, beaya, dan kemungkinan lainnya. Klinger menyatakan bahwa istilah komitmen lebih menunjuk pada "kuatnya usaha seseorang mengejar tujuannya, atau seseorang benar-benar setia terhadap tujuannya".

Allen, Meyer dan Herscovitch dalam Bantein dkk.(2005) mengkondepkan komitmen dalam tiga (3) dimensi yang merefleksikan perbedaan komponen yang mendasari konstruk komitmen. Masing-masing dimensi merefleksikan perpektif dari komitmen tersebut. Dimensi 
yang pertama adalah affective commitment ( $A C$ ), dimensi ini mewakili gagasan bahwa seseorang memiliki komitmen terhadap organisasi karena didorong oleh suatu kelekatan dan identifikasi emosional dengan organisasi. Contohnya, karyawan yang sangat mengabdi pada perusahannya. Dimensi kedua, adalah normative commitment $(N C)$ atau perasaan tanggungjawab moral untuk bekerja pada organisasi. Contoh mahasiswa, karyawan dan dosen terhadap Universitas atau Fakultasnya. Bentuk yang ketiga, adalah continuance commitment $(C C)$ atau kelekatan perasaan didasarkan pada kerugian bila tidak melanjutkan pekerjaan. Contoh:karyawan di perusahanperusahan yang lebih memperhitungkan kepentingan dirinya saja daripada perusahannya.

Allen dan Meyer (1990), menyatakan bahwa karyawan-karyawan dengan komimen afektif yang kuat, tetap berada pada organisasi karena mereka menginginkan (want to), karyawan dengan komitmen continuance yang kuat karena mereka membutuhkan (need to), sebab mereka merasa sudah seharusnya melakukan yang demikian (ought to).

Menurut Solinger dkk(2008), sekalipun komitmen organisasi dipahami sama dengan memahami konstruk komitmen afektif, ditegaskan bahwa menggunakan suatu definisi tidak dibatasi pada definisi itu saja, tetapi termasuk juga aspek-aspek kognisi dan_perilaku. Solinger dkk, mendefinisikan komitmen organisasi, sebagai sikap karyawan dalam hubungannya dengan organisasi, merefleksikan kombinasi pengaruh antara identifikasi dan kelekatan emosional dan kognisi (indentifikasi dan internalisasi dari tujuan, norma dan nilai), serta bersedia melayani dan meningkatkan kepentingan organisasi.

Berdasarkan pengertian komitmen di atas, dapat disimpulkan bahwa komitmen merupakan sikap seseorang yang sadar membentuk perilaku yang sesuai dengan tujuan, nilai, norma serta siap melayani dan meningkatkan kepentingan organisasi. Dari ketiga bentuk komitmen yang dijelaskan, menurut saya, komitmen afektif dan komitmen normative merupakan komitmen yang bernilai positif. Dikatakan demikian karena komitmen afektif didasarkan pada kemauan yang menunjuk pada dorongan dari dalam diri seseorang untuk bekerja pada sebuah organisasi. Kemauan yang berasal dari dalam diri seseorang dapat diartikan sebagai suatu kesungguhan atau kebulatan tekad untuk melakukan pekerjaan, karena menyenangi pekerjaan tersebut. Sama halnya dengan komitmen normative yang didasarkan pada perasaan tanggungjawab secara moral terhadap organisasi. Karyawan yang memiliki komitmen normative 
yang kuat akan mengutamakan kualitas kerja pada jalur-jalur aturan yang berlaku, karena seharusnya demikian. Berbeda dengan komitmen kontinuans, komitmen ini memiliki nilai negative, karena karyawan yang memiliki komitmen kontinuans yang kuat, lebih cenderung mempertimbangkan kepentingan diri atau keuntungan bagi dirinya. Dengan kata lain komitmen terhadap organisasi rendah, jika ada kesempatan ia akan meninggalkan organisasi.

Marcia dan Archer (1993), mengemukakan model identitas ego, dalam kaitan dengan teori perkembangan tentang pembentukan identitas pada remaja berusia 18-22 tahun, yang digolongkan sebagai remaja akhir (late adolescence). Dijelaskan bahwa pada usia yang demikian seseorang berada dalam proses membentuk pandangan (cognitive) serta perilakunya (behavioral) terhadap pilihan seperti:agama, bidang studi, pekerjaan, teman hidup dan lain-lain. Pengambilan keputusan terhadap pilihan-pilihan tersebut, sangat ditentukan sejauh mana ia mengekplorasi pilihan-pilihan itu berkaitan dengan status identitasnya.

Eksplorasi dimaksud dari segi kognitif maupun perilaku. Misalnya seseorang membuat keputusan untuk memilih bidang studi tertentu, maka pilihan tersebut tidak sekedar berdasarkan pengamatan saja, tetapi memahami secara detail melalui pendidikan maupun latihan yang berkaitan dengan bidang pekerjaan yang akan ditekuninya nanti. Keputusan untuk menetapkan pilihan dengan penilaian akan kemampuan dirinya atau merasa cocok dengan pilihannya. Selain itu pilihan tersebut didasari pada penilaian terhadap gambaran nyata dari aktifitas pekerjaan yang akan dilaksanakannya. Jadi keputusan atas pilihan tersebut sekaligus merupakan komitmen dirinya.

Bila dihubungkan dengan komitmen mahasiswa_yang belajar di Universitas Kristen Indonesia Maluku (UKIM), maka dapat dikatakan komitmen mereka merupakan sikap yang didasarkan pada kemauan atau dorongan dari dalam diri, karena merasa cocok atau senang dengan bidang-bidang studi yang akan dipelajari sebagai bagian dari persiapan dalam rangka mewujudkan harapan atau cita-citanya. Karenanya, pandangan, sikap dan perilaku mesti sesuai dengan tujuan yang hendak dicapai. Hal dimaksud adalah mekakukan tugas-tugas belajar sesuai dengan nilai dan norma yang berlaku umum di UKIM, dan secara khusus pada Fakultas yang dipilih oleh mahasiswa. Memiliki komitmen paling tidak diperlihatkan melalui: 
- Ketekunan, yakni sikap rajin dan bersungguh-sungguh ditunjukkan mahasiswa dalam tugas-tugas belajar. Ketekunan merupakan wujud dari kesadaran dan kemauan yang kuat untuk melakukan berbagai aktifitas yang berkaitan dengan pencapaian harapan atau cita-cita. Ketekunan adalah juga wujud dari sikap senang dan cinta sekaligus semangat untuk melakukan aktifitas belajar. Mahasiswa yang tekun melakukan tugas-tugas belajar, yakni tidak menyerah ketika menghadapi kesulitan dalam mengejar cita-citanya. Dengan kata lain tantangan atau kesulitan bukan penghalang, tetapi merupakan pendorong untuk terus berusaha dengan sungguh-sungguh sampai menggapai tujuannya. Ketekunan merefleksikan kekuatan sikap seseorang yang terus-menerus mengerjakan aktifitas yang bernilai dan bermakna bagi dirinya. Ketekunan juga dapat diartikansebagai kesetiaan seseorang terhadap tujuan hidupnya. Dengan demikian dapat dikatakan bahwa ketekunan menunjuk pada aspek komitmen afektif.

- Ketaatan, yakni kesadaran dan kesediaan yang sungguh-sungguh untuk mematuhi tuntutan dan peraturan-peraturan yang berlaku di lingkungan UKIM atau masing-masing Fakultas. Peraturan-peraturan tersebut berfungsi mendidik, membimbing dan mengarahkan mahasiswa untuk bersikap dan berperilaku sesuai dengan tujuan dari Fakultas maupun mahasiswa sendiri. Mahasiswa diharapkan bersikap taat atau patuh serta bertahan meskipun aturan yang berlaku ketat. Ketaatan merupakan wujud dari sikap disiplin untuk memenuhi ketentuan yang berlaku. Jadi dapat dikatakan ketaatan atau kepatuhan dalam konteks mengikuti pendidikan dan pembinaan sebagai persiapan dalam rangka mencapai tujuan mahasiswa. Dapat dikatakan sikap taat tersebut bukan merupakan suatu tekanan atau paksaan dari pihak Fakultas atau Universitas, tetapi ketaatan merupakan bagian dari komitmen yang dilakukan dengan ikhlas. Jadi ketaatan merupakan bagian dari spiritualitas yang perlu dipelihara sebagai kebiasaan hidup demi mewujudkan nilai,dan norma sebagaimana layaknya pelayan gereja dan pengabdi masyarakat. Dengan demikian dapat disimpulkan bahwa ketaatan mahasiswa terhadap peraturan merupakan hal yang tidak terpisahkan dari persiapan diri untuk bekerja atau melayani dalam Gereja dan Masyarakat. 
Konsisten, yakni sikap tidak berubah-ubah, hal ini dikaitkan dengan motif atau alasan mahasiswa mahasiswa masuk atau mengikuti pendidikan di UKIM. Dengan kata lain, kemauan yang dinyatakan pada awal masuk Fakultas, perlu diperlihatkan secara sadar melalui sikap konsisten yang kuat selama mengikuti pendidikan. Sikap konsisten diperlukan untuk mengerjakan tugas-tugas belajar, maupun mentaati peraturan yang berlaku. Sikap konsisten mahasiswa merupakan wujud dari kesungguhan mereka mencapai harapan atau cita-citanya. Dikatakan demikian karena komitmen untuk menjadi pendeta dan guru PAK pada mahasiswa Fakultas Teologi, menjadi pekerja sosial, politikus bagi mahasiswa Fakultas Ilmu Sosial dan Politik, ekonom bagi mahasiswa Fakultas Ekonomi, tekhnokrat bagi mahasiswa Fakultas Tehnik, perawat bagi mahasiswa Keperawatan dan Kesehatan Lingkungan, berkaitan dengan pilihan hidup seseorang. Pilihan untuk bekerja atau melayani jemaat/gereja Karenanya, selama menjadi mahasiswa sikap dan perilaku konsisten perlu dijadikan sebagai karakter hidup yang menunjang pekerjaan atau pelayanannya nanti dalam gereja dan masyarakat.

Demikian pula bagi seratus tiga puluh tiga (133) orang dosen, dan sembilan puluh enam (96) orang karyawan/karyawati, yang memilih bekerja di UKIM, bila pilihannya didasakan pada komitmen afektif dan normatif yang kuat, maka pekerjaan yang dijalani sesehari dipahami sebagai pekerjaan yang bermakna dan penting bagi diri, juga orang lain. Jika bekerja di UKIM dinilai bermakna dan penting, maka yang mesti terjadi adalah semua komponen bersinergi membangun UKIM sebagai institusi atau organisasi agar menjadi lebih baik dan maju.

Hunter (1990) mengemukakan komitmen sebagai kesanggupan memberi diri atau mengikat diri dalam hubungan dengan melakukan sesuatu dalam kehidupan. Menurutnya, konsep dasar teologis yang berkaitan dengan komitmen adalah perjanjian (covenant).Perjanjian dapat dikaitkan dengan berbagai tema, salah satu misalnya panggilan (calling) untuk pekerjaan (vocation). Bila dihubungkan dengan bekerja di UKIM, mesti dipahami bahwa bekerja bukan hanya sebagai cara untuk mendapatkan upah, tetapi bekerja dipahami sebagai "panggilan" untuk mengabdi dan melayani, maka jenis pekerjaan apapun yang dijalani setiap hari, perlu dilakukan dengan baik. Dengan demikian tugas mengajar, tugas administrasi, tugas di laboratorium, tugas 
kebersihan maupun tugas keamanan akan dijalaninya dengan tekun, rajin dan taat pada aturan yang berlaku.

Hall dan Chandler (2005) mengutip laporan penelitian dari Wrzesniewski, McCauley, Rozin, dan Schwartz, menyatakan bahwa orang-orang yang merasa terpanggil mengalami kepuasan tertinggi dalam hidup dan pekerjaannya serta memiliki tingkat mangkir terendah, jika disbanding dengan orang yang memiliki orientasi lain. Jadi jika semua dosen dan karyawan/karyawati yang bekerja di UKIM memiliki pandangan seperti yang dikemukakan Wrzesnieski dkk. Dalam Hall dan Chandler, maka tidak ada pihak yang dirugikan (mahasiswa ataupun UKIM). Hal ini merupakan point penting dalam pengabdian dan pelayanan dan karyawan/karyawati terhadap seluruh komponen civitas academika. Karena dosen dan karyawan/karyawati merupakan komponen penting bagi hidup dan berkembangnya sebuah Perguruan Tinggi.

Menurut Schunk dkk.(2008), istilah motivasi berasal dari kata kerja Latin movere (to move), atau bergerak yang merefleksikan gagasan tentang motivasi sebagai dorongan dari dalam diri seseorang untuk melakukan suatu pekerjaan. Motivasi telah dikonsepkan dalam berbagai cara, termasuk daya dari dalam diri, sifat-sifat yang berlangsung terus-menerus, yang membentuk pengaruh dan kepercayaan. Motivasi juga dihubungkan dengan kemauan dan kehendak. Schunk dkk. Mendefinisikan motivasi sebagai proses untuk mendorong dan memperkuat aktifitas menuju tujuan. Jadi kemauan dan kesediaan untuk dididik membutuhkan suatu proses belajar-mengajar yang mendorong kemauan dosen dan mahasiswa untuk lebih memperkuat aktifitas belajar-mengajar demi mencapai tujuan yang dicita-citakan. Shunk dkk menegaskan bahwa motivasi membutuhkan aktifitas fisik dan mental. Aktifitas fisik mencakup usaha yang sungguh-sungguh atau ketekunan serta tindakan-tindakan lain yang diperlukan. Sedangkan aktifitas mental, meliputi aktifitas kognitif seperti perencanaan, mengatur, atau mengorganisir, memecahkan masalah dan pengambilan keputusan serta menilai kemajuan yang dicapai.

Pandangan Shunk dkk. (2008) tentang motivasi di atas, menginspirasi mahasiswa agar berusaha sungguh-sungguh, tidak menyerah ketika mengerjakan tugas-tugas belajar sekalipun banyak. Dikatakan demikian karena dalam kenyataan misalnya, ada mahasiswa yang tidak 
berusaha secara maksimal mengerjakan tugas-tugas yang diberikan. Tugas mandiri kadang dikerjakan bersama atau copy tugas teman, tugas kelompok tidak dikerjakan semua anggota kelompok. Perencanaan studi tidak dilakukan dengan baik, sehingga mempengaruhi nilai mata kuliah dan waktu studi seseorang. Misalnya ada mahasiswa yang menawarkan mata kuliah lanjutan (yang disajikan semester atas) tanpa menawarkan ulang mata-kuliah yang nilainya perlu diperbaiki. Ada mahasiswa yang cuti kuliah pada pertengahan semester, keputusan untuk cuti kuliah tersebut perlu dikonsultasikan dengan Penasehat Akademik, karena akan mempengaruhi masa studi seorang mahasiswa.

Perencanaan studi mahasiswa, erat kaitannya dengan tanggungjawab atau kewajiban dosen Penasekat Akademik (P.A). Kadang PA tidak melaksanakan fungsi control akademik terhadap mahasiswanya dengan cermat dan menyerahkan tugas tersebut kepada Jurusan atau Program Studi (progdi). Hal ini tidak membantu mahasiswa untuk mencapai target waktu kuliah seperti yang direncanakan semula. Kelalaian PA dalam mengontrol perencanaan studi mahasiswa, bias saja disebabkan karena seorang dosen harus menjadi PA untuk sekian banyak mahasiswa (perbandingan ratio dosen-mahasiswa tidak berimbang). Menurut Standart Penjaminan Mutu UKIM, untuk ilmu eksata, ratio dosen : Mahasiswa $1: 20$, sedangkan non eksata $1: 30 / 40$.

Mengacu pada jumlah mahasiswa terdaftar semester genap tahun akademik 2013/2014 sampai dengan tanggal 05 Maret 2014, mahasiswa Fakultas Tehnik terdaftar tiga ratus tujuh puluh tujuh (377) orang, sedangkan jumlah dosen tehnik dua puluh dua (22) orang, data ini diperoleh dari bagian Akademik. Jika dihitung ratio $1: 20$, maka mestinya mahasiswa tehnik dalam perencanaan studi lebih terarah, karena perbandingan jumlah dosen dan mahasiswa termasuk kategori seimbang. Berbeda dengan mahasiswa keperawatan terdaftar depan ratus emat puluh tujuh (847) orang, jumlah dosen tujuh (7) orang, bila dihitung perbandingan ratio dosen 1: 40 mahasiswa, maka terlihat sangat tidak seimbang. Jadi jika dihitung perbandingan ratio dosen : mahasiswa per Fakultas, akan terlihat ada Fakultas yang perbandingan dosen mahasiswa masuk kategori baik, memadai dan sangat tidak memadai.

Mengatur atau mengorganisir kegiatan belajar, perlu sekali diperhatikan oleh mahasiswa, hal ini berkaitan dengan pencapaian prestasi belajarnya. Dari pengamatan saya PA atau dosen 
tutor dan sebagai pengampuh mata kuliah, ada indikasi bahwa tidak semua mahasiswa kegiatan belajarnya dengan baik. Misalnya mahasiswa yang tinggal di tempat-tempat kos,agaknya tidak menggunakan waktu semaksimal mungkin untuk mengerjakan tugas-tugas belajarnya. Sama halnya dengan mahasiswa yang tinggal dengan saudara atau orang-tua wali, diantara mereka mengatakan kesulitan belajar karena lingkungan tempat tinggal tidak mendukung, (terlalu gaduh). Mahasiswa yang tinggal dengan keluarga atau saudara mengeluh, sulit memiliki waktu belajar yang optimal, karena harus mengerjakan tugas-tugas rumah di keluarga saudaranya itu.Kadang PA tidak mengetahui kesulitan mahasiswa berkaitan dengan aktifitas belajar mereka, sebab mahasiswa tidak mengungkapkan kesulitannya. Selain itu ada juga mahasiswa yang jarang bahkan tidak pernah mengikuti acara tutorial dengan dosen tutor dan teman-teman tutornya. Menurut saya apapun kesulitan mahasiswa berkaitan dengan mengatur atau mengorganisir kegiatan belajar, perlu dicari solusinya. Menurut Shunk dkk. (2008), bagaimanapun juga sebagian besarbaktifitas belajar mahasiswa dikaitkan dengan kesanggupan atau kemampuannya dalam rangka pencapaian tujuannya. Pandangan Shunk dkk. tersebut sangat menginspirasi mahasiswa mendorong dan memperkuat aktifitas fisik dan mental secara terarah.

Bagi dosen, mengatur dan mengorganisir tugas-tugas yang terkait tri dharma menjadi hal penting (peraturan Akademik UKIM pasal 60). Khusus bagi dosen yang menduduki jabatan structural, beban kerjanya menjadi lebih berat jika harus mengajar lebih dari SKS yang ditetapkan, beban kerja dosen struktural maksimal 12 SKS. Jika karena kesibukan yang berkaitan dengan tugas strukturalnya yang mengakibatkan kehadiran untk mengajar kurang dari 14 kali tatam muka, maka dosen tersebut dikenakan sanksi (sesuai dengan peraturan akademik pasal 62). Keputusan yang diambil, tidak boleh merugikan mahasiswa karenanya mahasiswa diberi nilai B sebagai nilai kebijakan. Sebagian mahasiwa merasa tidak senang, bagi mereka nilai kebijakan menguntungkan mahasiswa yang tidak bersungguh-sungguh belajar. Sebaliknya mahasiswa yang tidak maksimal belajar itu justeru merasa senang karena diuntungkan dengan nilai B. Dosen dengan tugas struktural perlu mengorganisir tugas mengajar dan tugas-tugas tri dharma PT sedemikian rupa, sehingga tida menyalahi aturan yang berlaku.

Bagi karyawan, mengatur dan mengorganisir serta melakukan tugas-tugas administrasi menjadi bagian penting dari tanggungjawabnya. Jika semua dosen dan karyawan/karywati yang bekerja di UKIM memiliki pandangan dan sikap seperti yang dikemukakan Wrzesnieski dkk. 
Dalam Hall dan Chandler (2005), maka tidak ada pihak yang dirugikan. Hal ini merupakan point penting dalam pengabdian dan pelayanan terhadap seluruh komponen civitas academika. Dosen, karyawan dan mahasiswa menjadi komponen penting untuk perkembangan dan kemajuan UKIM ke depan. Karenanya, komitmen dan motivasi yang kuat sangat diperlukan dari dosen, karyawan yang bekerja di UKIM, juga mahasiswa yang belajar di UKIM.

Motivasi melibatkan tujuan seperti yang ditegaskan Shunk dkk. (2008) contohnya, tujuan mahasiswa teologi adalah menjadi pendeta. Menjadi pendeta merupakan tujuan utamanya. Untuk mencapai tujuan utama ini, dibutuhkan waktu rata-rata lima (5) sampai tujuh (7) tahun, dapat disebut sebagai tujuan jangka panjang. Karenanya mahasiswa perlu mengatur atau merencanakan waktu studi mereka secermat mungkin, sedapat mungkin waktu studinya jika perlu kurang dari lima(5) tahun. Tujuan jangka pendek setiap semester atau setiap tahun perlu dicapai dengan baik. Jika mereka berhasil lulus mata kuliah-mata kuliah yang ditawarkan pada setiap semester, maka hal itu akan memperkuat motivasinya, juga membuat mahasiswa semakin percaya diri untuk mencapai tujuan jangka panjangnya. Dengan demikan dapat dikatakan bahwa motivasi mahasiswa berpengaruh terhadap rasa percaya diri, yang sekaligus memperkuat komitmen mereka untuk mencapai cita-cita dengan baik sesuai target waktu yang ditentukan.

Uraian di atas, sejalan dengan pernyataan Bandura, Locke dan Leatham, yang dikutip Shunk dkk. Mengemukakan dan menegaskan bahwa penentuan tujuan atau sasaran adalah kunci dari suatu proses motivasi. Mahasiswa yang memiliki cita-cita dan percaya diri, berusaha melalui aktifitasnya dan yakin mereka akan menggapai tujuannya. Shunk Menegaskan juga bahwa memulai suatu menuju tujuan, adalah penting tetapi sering sulit, karena hal itu membutuhkan komitmen sejak tahap awal. Bagaimanapun juga kemauan atau motivasi yang kuat untuk menjadi pendeta perlu didukung dengan komitmen yang kuat pula sejak awal. Hal ini berkaitan dengan cara pandang seseorang melihat adanya hubungan antara pendidikan yang ditekuni dengan pekerjaan yang akan dilakukannya. Jadi motivasi untuk menjadi pendeta diawali dengan melakukan semua aktifitas belajar dengan sungguh-sungguh karena hal itu bernilai bagi mereka. Dengan demikian dapat dikatakan bahwa motivasi mahasiswa tersebut didasarkan dorongan dengan teori self-determination, motivasi merefleksikan suatu tujuan yang disertai dengan tindakan. Tujuan tersebut dicetuskan dari diri sendiri atau dari luar dirinya. 
Hunter (1990), mengemukakan motivasi adalah kekuatan atau daya yang mendorong atau perilaku seseorang Motivasi mirip dengan belajar atau pengetahuan, sebab motivasi langsung mempengaruhi pikiran dan perilaku seseorang. Berdasarkan pandangan Hunter ini, dapat dikatakan bahwa motivasi dapat mendorong proses berpikir seseorang dan mengarahkan pada pembentukan perilaku untuk mencapai tujuan yang diharapkan. Bila dihubungkan dengan motivasi mahasiswa mengikuti pendidikan, maka kemauan dan kesediaan untuk dididik dan dibina dalam rangka pencapaian harapan atau cita-citanya tentu dilatarbelakangi oleh motif-motif tertentu.

Menurut hasil penelitian Cote dan Levine (1977), dikatakan bahwa ada lima (5) tipe motivasi mahasiswa masuk Perguruan Tinggi yang dapat diukur dengan skala Motivasi Masuk Perguruan Tinggi (SMMPT). Lima(5) indicator motivasi masuk perguruan tinggi yaitu :

a. Motif karir-materi, yaitu mereka yang masuk perguruan tinggi dilatarbelakangi motivasi melihat perguruan tinggi sebagai cara untuk memperoleh karier, uang, status, kesusksesan dan segala yang menyenangkan dalam hidup.

b. Pengembangan intelek pribadi, yaitu mereka yang masuk perguruan tinggi dengan motif lebih ditekankan pada pertumbuhan pribadi, melalui pembelajaran dan pengetahuan untuk memahami kerumitan yang terjadi sebagai sebagai suatu realitas kehidupan di dunia.

c. Motivasi kemanusiaan, yaitu mahasiswa yang masuk perguruan tinggi dengan motif keprihatinan atau menaruh perhatian kepada orang-orang kurang beruntung, ingin mengubah sistim demi memperbaiki keadaan dunia.

d. Harapan dan dorongan dari orang-tua atau keluarga, yakni motif mahasiswa masuk perguruan tinggi karena member respons terhadap harapan dari orang-tua, atau keluarga untuk mendapatkan gelar.

e. Tidak punya pilihan lain, yaitu mahasiswa tidak memiliki motivasi yang jelas masuk perguruan tinggi. Dengan kata lain mereka tidak tahu mengapa atau untuk apa masuk perguruan tinggi.

Dari ke lima motif yang dikemukakan Cote dan Levin, menurut saya motif b dan $\mathrm{c}$ memiliki nilai terbaik. Motif a dan d cukup baik, sedangkan motif e memiliki nilai negatif. 


\section{Dukungan Sosial}

Sarason dkk. dalam Vallone dkk. (2004), mendefinisikan dukungan lingkungan sosial sebagai tersedianya orang-orang yang dapat diandalkan, yang peduli, mengasihi dan yang bernilai bagi sesamanya. Thoits, dalam Vallon dkk. (2004) mendefinisikan dukungan sosial sebagai pemenuhan kebutuhan sosial yang dialami oleh individu karena adanya interaksi dengan orang lain.

Fisher dalam Vallon dkk. (2004), menyatakan dukungan sosial diharapkan menguntungkan mahasiswa karena dua(2) alasan utama. Pertama, dukungan sosial memiliki pengaruh utama untuk mengurangi stress dan kegelisahan, memberi kesejahteraan kepada individu. Sebagaimana individu dengan tingkat support tertinggi mengalami konsekwensi negarif sangat sedikit. Kedua, dukungan sosial dapat memfasilitasi coping dengan sukses sepanjang situasi yang menekan sebagai penahan pengaruh stress.

Hampir sama dengan pandangan di atas, Cohen dan Hoberman dalam Coffman dan Gilligan (2002), menyatakan bahwa dukungan sosial adalah dukungan yang diharapkan diberikan orang lain jika dibutuhkan. Penelitian yang dilakukan Cohen dan Wills, dalam Coffman dan Gilligan, menunjukkan bahwa dukungan sosial bias mengurangi stress yang dirasakan karena memberikan integrasi atau menyatukan seseorang kedalam komunitas, untuk meningkatkan mutu kehidupan secara menyeluruh.

Dukungan sosial memberikan stabilitas, prediktibilitas, dan afeksi positif. Pickens dan Fenton, dalam Barker (2007), endefinisikan dukungan sosial sebagai dukungan dari individuindividu dan lembaga-lembaga sosial kepada orang yang membutuhkan. Dukungan ini muncul dari suatu hubungan dekat antar perorangan juga dari lembaga-lembaga sosial bagi individu yang membutuhkan. Sejalan dengan pengertian-pengertian yang telah dikemukakan di atas, Gentry dan Kobasa, Wallston dkk., Wills dan Fegan dalam Searafino (2006), menyatakan dukungan sosial merujuk pada individu yang menerima bantuan dari orang-orang atau lembaga sosial, merujuk pada individu menerima bantuan dari orang-orang atau kelompok, bantuan tersebut berupa perhatian, penghargaan dan ketenangan. Dukungan tersebut berasal dari berbagai sumner yang berbeda, misalnya dari keluarga atau orang-tua, teman, anggota persekutuan. Orang yang menerima dukungan sosial percaya bahwa ia dikasihi, dihargai dan bernilai serta menjadi bagian 
dari jaringan sosial seperti satu keluarga atau persekutuan organisasi yang dapat membantu pada saat dibutuhkan.

Berdasarkan pengertian yang diberikan beberapa ahli di atas maka dapat disimpulkan dukungan sosial adalah banyaknya perhatian, bantuan, dan dorongan yang kuat dari orang-orang yang dikenal baik oleh mahasiswa yakni orang-tua,atau keluarga, dosen, karyawan dan temantemannya. Dukungan yang diberikan menguatkan komitmen mahasiswa untuk mewujudkan harapan atau tujuannya.

Indikator-indikator dukungan sosial dapat digambarkan sebagai berikut. Menurut Barker (2007) ada empat (4) dukungan sosial yaitu :

a. Dukungan instrumental, yakni dukungan langsung kepada seseorang dalam bentuk bantuan keuangan, latihan ketrampilan, pelayanan kesehatan, transportasi dan lainlain.

b. Dukungan informasi, meliputi pemberian informasi tentang suatu kebutuhan yang berkaitan dengan yang diperlukan oleh individu.

c. Dukungan afiliasi, secara sederhana berarti ada bersama orang lain yang mempunyai minat yang sama.

d. Dukungan emosional, yang berasal dari teman-teman dekat, anggota keluarga termasuk orang-tua, atau dari para ahli yang menyediakan bantuan untuk kebutuhan emosional pada saat seseorang dalam krisis.

Jenis -jenis dukungan sosial yang dikemukakan oleh Cutrona dan Russel, Schaefer, Coyne dan Lazarus; Wills dab Fegan dalam Serafino (2006), sebagai berikut:

a. Dukungan emosional atau penghargaan berupa empati, sikap peduli, prihatin, perhatian positif, dan dorongan kepada seseorang. Semua itu diberikan untuk ketenangan dan ketentraman dengan suatu perasaan kasih, ketika seseorang berada pada saat tekanan.

b. Dukungan tangible atau instrumental, meliputi bantuan langsung berupa uang, untuk meringankan beban atau tekenan yang diakibatkan karena kekurangan uang, ataupun waktu dan tenaga yang dibutuhkan. Dukungan informasi meliputi pemberian nasehat, petunjuk, sugesti atau umpan balik 
tentang bagaimana seseorang dapat melakukan suatu hal. Sebagai contoh seorang yang sakit dapat memperoleh informasi dari keluarga atau dokter tentang bagaimana mengobati penyakitnya.

c. Dukungan persahabatan atau companionship menunjuk pada kesediaan orang Lin untuk membagi waktu dengan seseorang, member perasaan persahabatan dalam suatu kelompok dari orang-orang yang memiliki minat dalam kegiatan sosial.

Di sini dikemukakan hasil penelitian tentang dukungan sosial di kalangan mahasiswa seperti yang dikemukakan oleh Coffman dan Gilligan (2002), bahwa dukungan sosial tertinggi ditemukan pada mahasiswa yang sering melakukan kontak sosial dengan orang-orang yang bersedia memberi dukungan sosial kepadanya.

Dukungan sosial yang didapat mahasiswa menguntungkan mereka dalam hal merasa senang atau puas. Berdasarkan hasil temuan ini, menurut saya ada pengaruhnya terhadap kesehatan psikologis maaahasiswa. Dengan kata lain dukungan sosial yang diperoleh mahasiswa akan memperkuat motivasi dan komitmennya untuk melaksanakan tugas-tugas belajar yang sulit sekalipun, demi mencapai harapan atau cita-citanya.

Ostrow, Paul, Dark, dan Berhman dalam Coffman dan Gilligan (2002), menemukan bahwa dukungan yang diperoleh dari relasi dengan orang lain, memampukan mahasiswa untuk menguasai dengan baik tuntutan belajar di lingkungan perguruan tinggi. Menurut saya orang lain yang dimaksudkan di sini adalah orang-orang yang menaruh perhatian terhadap proses belajar mahasiswa. Mereka adalah orang-tua, keluarga, teman-teman dekat, dosen penyaji mata-kuliah, maupun dosen penasehat akademik atau dosen tutor.

Napoli dan Wortman (1998), mengemukakan bahwa mahasiswa yang memiliki tingkat dukungan sosial yang tinggi dari teman-teman dan keluarganya bisa memperoleh nilai rata-rata yang tinggi, mereka juga menunjukkan tingkat penyesuaian sosial dan tingkat akademik yang lebih tinggi pula. Demikian juga Solberg dan Valdes dalam Vallone dkk.(2004) meneliti 394 mahasiswa Latin/Hispanik dan menemukan bahwa dukungan sosial berkorelasi positif dengan penyesuaian kampus secara menyeluruh. Selanjutnya hasil penelitian Jay dan D'Augelli dalam Vallone dkk. (2004) yang meneliti 165 mahasiswa Kaukasian dan mahasiswa dari Afrika- 
Amerika, dengan tingkat dukungan sosial yang tinggi menunjukkan self-report yang tinggi, selanjutnya juga berkaitan dengan tingkat penyesuaian psikologis yang tinggi. Menurut Vallone dkk (2004), karena dukungan sosial berkontribusi terhadap penyesuaian kampus, maka dimungkinkan bahwa dukungan sosial memiliki pengaruh terhadap komitmen mahasiswa terhadap universitasnya, maupun tingkat retensi secara keseluruhan. Napoli dan Wortman, dalam Vallone dkk., menyatakan bahwa mahasiswa yang memiliki komitmen yang tinggi terhadap tujuan institusional, memiliki kecenderungan lebih besar untuk menunjukkan ketekunan yang lebih tinggi pula.

Berdasarkan konsep-konsep teori, pandangan, terutama dari hasil temuan para ahli di atas, dapat disimpulkan bahwa dukungan sosial sangat berpengaruh terhadap keberhasilan studi mahasiswa. Mahasiswa yang belajar di UKIM, berasal dari berbagai tempat di wilayah Maluku. Untuk kepentingan belajar di UKIM, sebagian diantara mahasiswa tinggal di tempat/kamar kos. ada juga mahasiswa yang tinggal dengan saudara atau keluarga, tapi ada juga yang tinggal dengan orang-tuanya. Hasil percakapan saya dengan beberapa mahasiswa yang tinggal di rumah keluarga, maupun yang tinggal di tempat/kamar kos, ternyata mereka menghadapi berbagai persoalan. Misalnya mahasiswa yang tinggal dengan keluarga atau saudara, mereka sulit mengatur waktu belajar, karena harus melakukan pekerjaan-pekerjaan rumah tangga, juga masalah keterlambatan pengiriman beaya dari orang-tua. Khusus bagi mahasiswa yang tinggal di tempat kos keterlambatan pengiriman beaya hidup dari orang-tua, mengakibatkan mahasiswa kadang harus menahan lapar, bahkan sampai sakit maag. Permasalahan mahasiswa seperti ini berpengaruh juga terhadap kesehatan psikologis, seperti menurun semangat belajar, mengakibatkan tugas-tugas belajar tidak dikerjakan dengan maksimal, atau tidak dikerjakan sama sekali. Dalam kenyataannya mahasiswa-mahasiswa yang mengalami kesulitan keuangan, tidak terbuka kepada penasehat akademik atau dosen tutornya, bahkan ada yang jarang sekali terlibat dalam aktifitas tutorial. Mereka ini perlu diberi dukungan sosial oleh dosen penasehat akademik, jika ada informasi yang disampaikan teman dekat mahasiswa yang bersangkutan kepada penasehat akademiknya. Dukungan yang diberikan berupa dukungan material atau dukungan finansial seperlunya untuk menolong mahasiswa mengatasi kebutuhan perutnya. Penasehat akademik perlu memberikan dukungan informasi agar mahasiswa mengatasi kesulitan belajar, bagaimana mahasiswa mesti menyesuaikan diri dengan tuntutan belajar di Fakultas. 
Dukungan informasi, berkaitan dengan penasehat akademik menemukan sumber-sumber belajar seperti buku atau jurnal yang diperlukan untuk tugas-tugas belajar mahasiswa. Bagi mahasiswa yang sering terlambat menerima kiriman beaya dari orang-tua, penasehat akademik bisa menginformasikan tentang orang-orang yang dikenal baik yang bisa member kerja paruh waktu untuk mengatasi kesulitan keuangan mahasiswa. Dukungan emosi diberikan untuk menolong mahasiswa, agar tidak meninggalkan komitmennya untuk menggapai tujuan atau harapannya.

Dukungan sosial atau dukungan informasi, finansial, persahabatan, tidak hanya dibutuhkan oleh mahasiswa yang belajar di UKIM, tetapi juga menjadi kebutuhan karyawan/karyawati bahkan dosen-dosen ketika berhadapan dengan situasi-situasi tertentu. Karenanya, penciptaan lingkungan kerja yang saling mendukung menjadi salah satu tuntutan Tinggi dan Gereja Protestan Maluku (YAPERTI GPM) memiliki tanggungjawab mendukung seluruh aktifitas belajar-mengajar yang terjadi di UKIM.

\section{Self-Efficacy}

Bandura (1986), mendefinisikan self-efficacy sebagai penilaian seseorang tentang kemampuan dirinya untuk mengatur dan melaksanakan tindakan demi mencapai jenis-jenis prestasi yang dikehendaki. Pada sumber yang berbeda Bandura (1977), mendefinisikan selfefficacy sebagai kepercayaan atau keyakinan seseorang untuk mengatur dan melaksanakan kemampuan-kemampuannya demi mencapai hasil yang diinginkan. James E. Maddux (2005), mendefinisikan self-efficacy sebagai kepercayaan terhadap kemampuan yang dimiliki seseorang untuk dapat mengkoordinasi kemampuan-kemampuan dan ketrampilan-ketrampilan yang ada pada dirinya untuk mencapai tujuan yang diinginkan pada bidang tertentu dan dalam keadaan tertentu. Hampir sama dengan pandangan Bandura, Goleman (1999), menyatakan bahwa selfefficacy adalah penilaian positif tentang kemampuan kerja diri sendiri. Self-efficacy tidak sama dengan ketrampilan sesunggguhnya yang dimiliki seseorang, tetapi cenderung berupa keyakinan mengenai apa yang dapat dikerjakan dengan ketrampilan yang dimilikinya.

Zimmerman (2000), mengemukakan bahwa self-eficacy berperan memotivasi siswa/mahasiswa untuk belajar khusus dalam bidang akademik, yakni kemampuan untuk mengatur aktifitas belajar mereka sendiri. Berdasarkan pandangannya ini, dapat dikatakan bahwa percaya diri atau self-efficacy berperan penting terhadap pengelolaan aktifitas siswa ataupun 
mahasiswa dalam rangka pencapaian target-target belajarnya. Dengan adanya kemampuan mengatur atau mengelola aktifitas belajar akan membantu siswa atau mahasiswa untuk menilai dan mengontrol pencapaian atau keberhasilan belajar setiap semester, maupun setiap tahun pelajaran/akademik. Dengan demikian dapat dikatakan bahwa rasa percaya diri (self-efficacy), merupakan kunci yang menentukan keberhasilan belajar, maupun dalam usaha lainnya.

Heslin dan Klehe (dikutip oleh Rogelberg, 2006) menemukakan bahwa seseorang yang memiliki rasa percaya diri yang kuat pada kemampuannya akan berhasil melakukan suatu tugas khusus. Rasa percaya diri (self-efficacy) pada seseorang merupakan kekuatan motivasi yang sangat menentukan bagaimana seseorang berusaha keras melakukan apa saja dengan baik. Dikemukakan juga bahwa self-efficacy seseorang merupakan suatu kekuatan yang ditentukan oleh usaha, ketekunan, dan strategi, maupun prestasi pada saat latihan maupun pekerjaan mereka yang berikutnya. Berdasarkan rumusan pengertian dan pandangan para ahli tentang self-efficacy di atas, maka dapat disimpulkan bahwa self-efficacy merupakan rasa percaya diri atau keyakinan diri atau keyakinan mahasiswa terhadap kemampuan dan ketrampilan mereka dalam melaksanakan tugas-tugas belajarnya.

Ada tiga dimensi penting yang berbeda pada implikasi efficacy belief yang dapat dilaksanakan. Pertama, level atau tingkatan. Perasaan efficacy seseorang berbeda dari individu yang lain ditentukan oleh banyaknya tugas dari yang mudah sampai mencakup tugas-tugas yang sulit, termasuk melaksanakan sebagian besar tugas dalam suatu bidang khusus. Self-Efficacy seseorang diukur berdasarkan tingkat kesulitan tugas yang mewakili berbagai derajat kesukaran yang berhasil dilakukannya. Shunk, dkk., (2008) menyatakan bahwa mengukur self-efficacy para siswa, para peneliti sering menunjukkan contoh tugas-tugas yang diberikan kepada siswa dengan tingkat kesulitan yang berbeda. Siswa dapat menilai tingkat percaya diri mereka dalam menyelesaikan dengan sukses jenis-jenis tugas tersebut. Misalnya seperti menemukan gagasan utama atau ide pokok pada alinea, menyusun alinea, menyelesaikan tugas pecahan, melekukan eksperimen di laboratorium.

Kedua, strength atau kekuatan akan keyakinan yang dimiliki seseorang. Self-Efficacy terletak pada seberapa kuat keyakinan seseorang untuk melaksanakan tugas yang diberikan. Seseorang dapat memperbaiki dan meningkatkan penilaian terhadap efficacy-nya dengan 
memperkuat keyakinannya, sekalipun menghadapi rintangan yang sulit. Karena keyakinan yang kuat akan membuatnya berhasil. Dengan kata lain keyakinan yang kuat, menentukan keberhasilan seseorang dalam melaksanakan tuntutan tugas yang diberikan.

Ketiga, general seseorang dapat menilai efficacy dirinya melalui aktifitas yang lebh banyak atau lebih umum, atau hanya berfungsi pada bidang tertentu saja. Generalitas dapat berbeda pada sejumlah dimensi, termasuk tingkat aktifitas, demikian halnya dengan merasa mampu dapat ditunjukkan melalui perilaku kognitif dan afektif kepada orang lain. Penilaian tentang efficacy mereka dihubungkan dengan bidang-bidang aktifitas dalam bentuk dan tingkatan yang lebih bersifat umum atau khusus, dimana mereka merasa yakin pada efficacy-nya. Dalam hubungan dengan keyakinan efficacy, ada beberapa bidang khusus yang dianggap terbaik dan penting dari pada yang lainnya. Berdasarkan uraian di atas, maka indikator yang digunakan dalam penelitian ini adalah dimensi level dan dimensi khusus. Dimensi level atau tingkat kesulitan digunakan untuk mengukur pengetahuan dan pemahaman.

Pada mahasiswa Fakultas Teologi misalnya, bahasa-bahasa asli Alkitab (bahasa Ibrani, Yunani, Hermeneutika Perjanjian Lama dan Perjanjian Baru). Pengetahuan dan pemahaman bahasa Ibrani dan Yunani diperlukan untuk mengetahui makna teks dan konteks pada masa lalu (pada saat teks Alkitab itu di tulis). Hermeneutika Perjanjian Lama dan Perjanjian Baru diperlukan untuk memaknai secara baru pada konteks masa kini. Sedangkan dimensi khusus digunakan untuk mengukur tingkat penguasaan pelajaran yang membutuhkan ketrampilan mereka. Self-Efficacy juga berkaitan dengan kekhususan digunakan untuk mengukur ketrampilan memahami perasaan dan pikiran yang tidak dikatakan dalam bahasa verbal dari teman atau orang lain dalam konseling pastoral. Ketrampilan memahami pikiran dan perasaan konseli yang tak terkatakan sangat penting dalam rangka menolong konseli berhadapan dengan masalah dan dirinya sendiri.

Self-Efficacy seorang mahasiswa dapat tumbuh dan berkembang jika didukung oleh lingkungan belajarnya. Terutama dalam interaksi mahasiswa-dosen, maupun interaksi sesama mahasiswa di kelas, dalam proses belajar-mengajar. Kadang dosen tidak membantu atau mendorong mahasiswa mengembangkan self-efficacy mereka, dengan memberi penghargaan, memuji, tapi juga mengarahkan pada yang benar atau tepat. Dengan kata lain pemikiran atau 
pandangan mahasiswa tidak perlu diberi komentar yang menyakiti atau melukai mereka. Karena hal itu akan membuat mereka tidak berani mengemukakan pemikiran atau pandangannya. Demikianpun di lingkungan pekerjaan, diharapkan atasan dapat menghargai pekerjaan staf. Jika pekerjaan belum sesuai target, perlu didorong atau disemangati agar staf dapat menunjukkan prestasi kerjanya. Sikap tegas dibutuhkan dalam mengarahkan karyawan/karyawati agar berdisiplin dalam melakukan tugas-tugas, sehingga prestasi kerja dapat dicapai.

\section{Penutup}

Kesusksesan belajar-mengajar dan mengabdi di Perguruan Tinggi (Universitas Kristen Indonesia Maluku), akan menjadi kenyataan jika semua komponen memperlihatkan komitmen yang kuat, memiliki motivasi belajar-mengajar dan mengabdi yang kuat, saling mendukung dan percaya diri dalam melaksanakan tugas-tugas yang dipercayakan.

\section{Daftar Kepustakaan}

Allen, N.J. \& Meyer, J.P. (1990). The measuremet and antecedent of affective, continuance, and normative commitment to the organization. Journal of Occupational Psychology, 52, 27-58.

Bandura, A. (1997) Self-Efficacy:the exerciseof control. NewYork: Freema.

Bandura, A. (1986). Social foundation of thought and action: A social cognitive theory. Dalam Marks, David,F.(ed).The Health Psychology Reader (pp. 94-104)

Bantein, K.,Vandenberghe, Ch,. Vansenberg, R., Stinglhamber, F.(2005). The role in the relationship between commitment and turnover: A latent growth modeling approach.Journal of Applied Psychology, Vol. 90 (30), 468-482.

Barker, G. (2007). Adolescents, social support and help seeking behavior: An International Literature review and program consultation with recommendations for action. Genewa: WHO Publication. 
Brickman, P. (1987). Commitment. In B.Wortman \& R.Sorrentino (eds.), Commitment, conflict, and caring (pp.1-18). Englewood Cliffts, N.J.: Prentice Hall.

Coffman, D.L. \& Gilligan, T.D. (2002). Social support, stress, and self-efficacy: Effect on student' satisfaction. Journal of College Student Retention, 4, (1) 53-64.

Goleman, D. (1999). Kecerdasan emosi untuk mencapai puncak prestasi.(Alih bahasa), Penerbit Gramedia. Judul Asli, Working with Emotional Intellegence. (Karya asli terbit1998).

Hall, D.T. \& Chandler, E. (2005). Psychology success: When the career is a calling.Journal of Organizational Behavior 26, 161-162.

Heslin, P.A. \& Klehe, U.C. (2006) Self-Efficacy. In Rogelberg (ed.), Encyclopedia of Industrial/Organizational Psychology. Vol. 2. 705-708.

Hunter, R.J. (ed). (1990). Dictionary of pastoral care and counseling. Michigan:Abingdon Press.

Klinger, E. Commitment. In Kasdim, A.(ed.) (2001). Encyclipedia of Psychology.(p.188191) APA, Washington DC:Oxford University Press.

Maddux, J.E. (2005). Self-Efficacy: The power of believing you can. In Synder, C.R. \& Lopez, S.J. (eds), Handbook of positive psychology, (p.227-287) New York: Oxford University Press.

Marcia, J.E. \& Archer, S.L. (1993). Ego Identity: A Handbook for Psychosocial Research. New York: Springer Verley.

Sarafino, E.P. Health Psychology Biopsychosocial Interactian. Fith Edition (2006). New Yersey: Jhon Wiley \& Sons, Inc.

Shunk, D.H., Pintrich, P.R. \& Meeca, JL.(2008) Motivation in Education: Theory, Research, and Aplication. Third Edition. New Yersey: Pearson Merril Prentice Hall.

Solinger, N., van Olffen, W., \& Roe, Robert A. (2008). Beyond the three-componet model of organizational commitment. Journal of Applied Psychology, 93, 70-83. 
Vallone, e.G.., Reid, K., Umali, Chr., \& Pohlert, E. (2003/2004). An analysis of effects of self-esteem, social support, and participation. Journal of College Student Retension, 5, (3) 255274.

Wrzesnieski, A., (2003). Finding positive menaningin work. In Cameron K.S., J.E., \& R.E. Quinn (eds.), Positive organizational scholarship:Foundations of a new discipline (pp.327247). San Fransisco: CA Berret-Koehler

Zimmerman, B.J. (2000). Self-Efficacy: An Essential Motive to Learn. Contemporary Educational Psychology 25, 82-91. 